\title{
Chronic acquired polyneuropathy
}

\section{An Erratum to B. Anlar et al.: "Chronic acquired polyneuropathy in infancy", J Neurol (2002) 249:1469-71}

\author{
Banu Anlar
}

Received: 19 December 2008/Accepted: 18 February 2009/Published online: 11 March 2009

(C) Springer-Verlag 2009

This family's second child, born 2 years after the index case died, was affected similarly. A metabolic disorder was extensively investigated in the second child, including DNA analysis in specialized laboratories for mitochondrial mutations. Although no metabolic defect or mutation was found which could explain the clinical picture, we strongly think this entity was not an acquired polyneuropathy but a metabolic defect yet unproven. We would like to inform readers about the change in the diagnostic consideration of our published case.

B. Anlar $(\bowtie)$

Department of Pediatric Neurology,

Hacettepe University, Ankara, Turkey

e-mail: banlar@hacettepe.edu.tr 